\title{
Defense Education Enhancement Program: The Kazakhstan Experience
}

\author{
Alan G. Stolberg *
}

\section{Introduction}

In 2008, the National Defense University of Kazakhstan (KAZ NDU) and the Partnership for Peace Consortium of Defense Academies and Security Studies Institutes (PfPC) agreed on a three-year program of cooperation. The intent of the program was PfPC support for KAZ NDU's attainment of international standards for both curriculum and teaching methodology. The program that was created was known as a DEEP — a Defense Education Enhancement Program. DEEP initiatives have a unique ability to provide support to Partner defense education institutions in the areas of curriculum and faculty development. For curriculum development, this could include the creation or refinement of courses or individual lessons, as well as support for the curriculum development of an entire new defense education institution. Faculty development could include pedagogy support in the areas of classroom teaching and evaluation techniques. The PfPC program in support of Kazakhstan is now in its fifth year, and will continue for several more.

\section{How it Began}

In the late winter of 2007, the Ministry of Defense of Kazakhstan (MoD) made a request to the United States Embassy to undertake an assessment of the KAZ NDU. This request was in accordance with Partnership Action Plan-Defense Institution Building (PAPDIB) objectives of the NATO-Kazakhstan Individual Partnership Action Plan (IPAP), agreed between Kazakhstan and NATO in January 2006. In response to the request, and as a component of the Defense Education Enhancement Program, this peer review was conducted by the PfPC, taking place at the direction of the Office of the U.S. Secretary of Defense (OSD) and in coordination with NATO with the intent of understanding the current composition of the defense education process conducted by the KAZ NDU. The broad areas to be examined included institutional purpose, organization, academic programs and curriculum, academic evaluation, student make-up, faculty qualifications, library resources, and Internet connectivity. A six-person team conducted the review from 10-13 December 2007. The team was composed of academic experts on subject matter directly related to the needs of the specific host educational institution. The source for the needs was found in the specific requests made by the institution and in the country's NATO-related IPAP. The team consisted of:

- Dr. Alan G. Stolberg, U.S. Army War College

- $\quad$ Dr. Jack Treddenick (Canadian), George C. Marshall Center

\footnotetext{
Dr. Alan G. Stolberg is Associate Professor of National Security Studies at the United States Army War College in Carlisle, PA.
} 
- Colonel George Teague, U.S. Army War College

- Colonel Cynthia Coates, U.S. Joint Staff J7

- Lieutenant Colonel Paul Riley, George C. Marshall Center

- Mr. Alexander Vinnikov, NATO International Staff.

The KAZ NDU head (director), General-Major Shoinbaev and his staff were extremely transparent and open. They exhibited a spirit of cooperation and the desire to learn from us (with "us" to be defined as "the West" writ large). Their long-term intent is to balance the Russian and Chinese influence on Kazakhstan's military education curriculum.

The KAZ NDU is the only higher defense education institution in the country. It is designed as a two-year residential program that results in the attainment of a Master's degree in one of three fields: Military Art, Military History, or Armaments Technology and Logistics. Using Western defense education systems as an analogy, the KAZ NDU curriculum primarily represents a spectrum of education and training that encompasses advanced course (captains), intermediate level education (Staff College; majors), and senior service college (War College; lieutenant colonels and colonels) level instruction.

The curriculum is situated more between the Staff College and War College levels. The student body has approximately sixty students per class, and is drawn from all parts of the government's security sector. The student body consists of captains through lieutenant colonels (O-3 through O-5). Each class is typically made up of about 53 percent of students from the Ministry of Defense, with the remainder coming from the Ministry of Internal Affairs, Border Guards, Ministry of Emergency Situations (or the Russian EMERCON equivalent), the Presidential Guard, and a number of foreign students.

The initial DEEP team explored the professional defense education components of military education, training, and doctrine with the NDU leadership. Specific areas discussed were the various curricula, which are broken down among six academic departments. At the conclusion of the assessment visit, the KAZ NDU head, General-Major Shoinbaev, stated that the curriculum had changed drastically in the last three to five years. Now, it sees the experience of other countries in reforming their defense education sectors, and it "does not want to be left behind." The NDU wants "to follow in the footsteps of leading countries, and in some areas take the lead (themselves)." The director also said that in recent years the focus of military thought in Kazakhstan had shifted from large conventional battles and wars to local wars and low-intensity conflict; therefore, "we must revise our curricula." He then said, "You are our strategic partner you can give us advice and proposals. We want to balance curriculum obtained from Russia and China." Finally, the director stated, "This was the first real, businesslike, content-filled meeting, in which I feel there is the potential for real cooperation."

The primary focus of the team's report concerned those specific areas of intensified cooperation desired by the KAZ NDU; this was to be a demand-driven program, in order to ensure maximum support from the host nation and its defense education institution. Prior to the actual visit to the site of the NDU, the DEEP team met with the Deputy Minister of Defense to confirm thinking within Kazakhstan's Ministry of Defense for the 
types of desired support for the NDU. From a KAZ MoD perspective, during the course of the review it appeared that one of KAZ NDU's primary goals was to assure the Ministry that their programs and methodologies had achieved acceptable international standards. There were major initiatives in place from both the Ministry of Education and Ministry of Defense to transform (or modernize) military education in Kazakhstan. The principal intent was to utilize the information derived from this review to develop a long-term program of cooperation that would enhance Kazakhstan's defense education from a Western perspective.

\section{The Initial Program of Cooperation}

In the case of the KAZ NDU, the recommendations contained in the initial three-year program of cooperation (which took place from 2008-11) proposed a series of programs and activities designed to assist the KAZ NDU to transform its way of doing business to varying degrees in the direction of the current approach found in defense education in the U.S. and other NATO states. The primary areas of focus for this transformation were in curriculum development, educator pedagogy, and distance learning. In essence, the program goals, in accordance with national IPAP objectives, were to be a Kazakh NDU with curriculum and pedagogy that are compatible with those in NATO/Western defense education institutions.

The U.S. Office of the Secretary of Defense approved this program, which was understood as a long-term process requiring focused detailed cooperative exchanges in those specific areas selected by the KAZ NDU. By mutual agreement, all specific programs and activities had to be specifically scoped for the exact requested issues to be addressed for the KAZ NDU, and only the KAZ NDU. None of the recommended visits or exchanges was to be combined with other institutions in or outside of Kazakhstan, which the exception of select multinational events held outside the country.

In summary, the multi-year program concept was structured as follows:

- Year 1: Initial cooperation visits and exchanges focused on specific subject matter

- Year 2: Both new and follow-up visits and exchanges, with program refinements as required

- Year 3: Emphasis on continued follow-up, with movement toward self-sufficiency in some areas, as well as the introduction of new subject areas to be addressed.

The results over time included additional time/years for program execution beyond the initial scope (in this case, three years), and would ultimately be that NATO/Western defense education goals would be attained for the host institution.

\section{Annual Review for Attainment of Objectives and Adjustment as Necessary}

The first three-year program of cooperation included the mutually agreed stipulation for a return visit on an annual basis by the leader of the PfPC effort for a review of the pro- 
gram's effectiveness. This visit would include a meeting with the Deputy Minister of Defense to ensure Ministry support, and would be repeated each year of the program's existence. It would be able to serve as a joint review with the host institution of the program's ability to meet the institution's needs during both the prior and forthcoming years. Based upon observations during these visits, program activities were adjusted as needed for the coming years. They included agreement on detailed administrative data for upcoming exchanges, such as the exact dates and numbers of personnel involved, as well as the precise substance of the events.

\section{Measures of Effectiveness}

Measures of effectiveness for the program were also identified in order to demonstrate that the program was either on track or required adjustment as necessary. In the case of the KAZ NDU, it was determined that effectiveness should be measured by the manner and extent that the NDU actively adopted specific changes proposed by the DEEP team. Holding a workshop, in and of itself, would not constitute success; adopting proposals made by the workshop would. Examples of success have included:

- Pedagogy events are having a positive influence on the KAZ NDU faculty. They are described by the KAZ NDU staff as "vital to transform[ing] the previous" teaching methodology. Interactive teaching techniques are now being used widely by the entire faculty. Students are being asked to "think," use "critical thinking" skills, and "exchange ideas." It is now also applied to gaming, exercises, and map-related operations planning.

- The KAZ NDU Maintenance Management Department has created a new course in the curriculum called "NATO Standards for Home Front Maintenance," and the KAZ NDU has created a long-term relationship with the Romanian NDU for maintenance and logistics issues.

- Leadership theory has been incorporated into the permanent curriculum's management course, and attendance at the November 2010 leadership and ethics workshop sponsored by the PfP Consortium and hosted by the Romanian NDU exposed faculty to the concept of having to defend their individual views.

- Iraq/Afghanistan air force, army aviation, and artillery lessons learned from an April 2011 event are now being formally incorporated into the curriculum by the Operational Arts Department; described as necessary "so as not to allow them to be trapped in old dogma."

- April 2011 lectures on Western interpretation and teaching of international humanitarian law are now included in the curriculum of a course titled "Basics of International Humanitarian Law.”

\section{Program Details}

Over the course of the first four years of the program's existence (2008-12), twentyseven individual events were executed by the PfPC in support of the KAZ NDU. These 
included curriculum development events that involved lectures by the visiting subject matter experts to students and faculty on KAZ NDU requested topics, as well as subject matter expert-conducted seminars on the same subject with KAZ NDU students. The lecturers would follow these events with peer-to-peer meetings with the related KAZ NDU faculty charged with teaching the same topics. The intent of these vital follow-on meetings is to provide the KAZ NDU faculty with the information required to teach the subject themselves (e.g., learning objectives, readings, audio/visual aids, types of questions to ask the students for evaluation, and the general teaching flow for the lesson). As of this writing, there have been twenty curriculum development events provided for the KAZ NDU, on the following subjects:

- Strategy Formulation

- NATO

- Management

- Logistics Maintenance Management

- Peace Support Operations

- PfPC Reference Curriculum

- Leadership Theory

- Defense Economics and Budgeting

- Leadership Workshop

- Support for New KAZ Ph.D. Program

- U.S./NATO Air Force/Army Aviation Iraq/Afghanistan Lessons Learned

- U.S./NATO Artillery Iraq/Afghanistan Lessons Learned

- Logistics Faculty Visit to a Counterpart NATO School

- Twenty-first Century Local Wars/Small Wars/Local Conflicts

- Western Views on International Humanitarian Law

- Military and State Control of the Armed Forces

- Cyber Defense

- National Military Strategy

- Military and Space

- Network Centric Warfare.

Several curriculum-related events were conducted under the direction or participation of other NATO members, and included the NDU Management NATO School Visit and Support for New Ph.D. Program (Canada); the Maintenance Management and Leadership Workshop events, and the Logistics Faculty Visit to a Counterpart NATO School (Romania); and the Reference Curriculum Team (mixed national team).

In addition, four faculty development events - each several days in duration-were held to assist in the transformation of the teaching methodologies used by the KAZ 
NDU faculty; one of these included a workshop specifically focused on how to conduct classroom exercises and simulations. Each one of these workshops involved multinational teams in the execution of the events. Also, two Russian-speaking faculty members from the Marshall Center were able to play an advisory role for two KAZ NDU students as they crafted the theses required of the Master's degree-granting program. Finally, four program reviews were conducted to determine the effectiveness and efficiency of the events carried out during the previous calendar year. In sum, a total of twenty-nine separate events in support of the KAZ NDU were conducted by a combination of the PfPC and NATO during the four-year period between October 2008 and November 2012.

\section{What's Next for the Program of Cooperation?}

In both June 2011 and June 2012, the Kazakh Ministry of Defense confirmed that they would like the program of cooperation to be continued, for at least another three years. The vast majority of events that were requested during the early stages of the program are no longer being requested. Given the premise that the KAZ NDU has now become self-sufficient in those initial areas, new events are being requested. Many of these requested programs focus on twenty-first century security challenges, such as the military and space, cyber defense, network-centric warfare, the information element of national power, and assistance with the creation of a Western operational art course that reflects U.S. and NATO experience in Iraq and Afghanistan. It is anticipated that approximately nine events per year will continue to be scheduled for the next several years.

\section{Summary}

Professional military education institutions in any country can have a significant long-term impact on the future leaders of the nation's armed forces. This very much seems to be the model that Kazakhstan has chosen to follow. The reinforcement of original lessons learned as a recruit or cadet in the classroom for senior noncommissioned officers and mid-senior officers can influence a professional military during the course of a career that spans twenty or thirty years. This is a major reason that Western militaries have changed over time, and arguably how most militaries are most easily able to adapt. If the curriculum being used at all levels of instruction supports the desired concepts for a professional military well-versed in key areas like the twenty-first century fighting skills that require initiative and creativity, alongside democratic and humanitarian oriented civil-military relations and working with good civil governance, then the likelihood exists that Kazakhstan's professional armed forces will be a good partner for their host domestic society, as well as for other state and institutional partners in the international system. If done right, real interoperability between the armed forces of Kazakhstan and the U.S. and NATO will be able to evolve beyond theory to practice. 